\title{
Excretion of lead and its biological activity several years after termination of exposure
}

\author{
I. PŘEROVSKÁ and J. TEISINGER \\ Clinic of Occupational Diseases, Prague
}

\begin{abstract}
Přerovská, I., and Teisinger, J. (1970). Brit. J. industr. Med., 27, 352-355. Excretion of lead and its biological activity several years after termination of exposure. A group of 27 persons who had been treated some years previously for chronic lead poisoning at our clinic, and who had not come into occupational contact with lead since, was examined. Half of them had had no occupational exposure to lead for 3 to 5 years and the others for 8 to 17 years. In most of these persons there is still an increased lead excretion, originating from an increased deposit in the bones. The mobilization test after calcium versenate (CaEDTA) injection was greater than $0.350 \mathrm{mg} / 24$ hours. The values found for haemoglobin, punctate basophilia, coproporphyrin and ALA in urine were normal, but there was, in all cases, a decreased ALA-D activity. This finding suggests biological activity of such negligible lead flow many years after termination of exposure.
\end{abstract}

We tried to show in a previous paper (Teisinger, Přerovská, Šedivec, Flek, and Roth, 1969) that the extent of biological reaction of the organism to the effect of lead depends on the size of the so-called active lead deposit in the organism. By this we understand lead which is easily mobilized and which is contained in soft tissues and in trabecular bone. We showed in rabbits that as this active deposit decreases the positiveness of biological tests rapidly decreases. In that paper we reported a study of haemoglobin level, the number of stippled red blood cells and coproporphyrinuria and showed that these tests are not over sensitive, as they remained negative at times when the active deposit of lead calculated by us still amounted to $25 \%$ of the original level. However, higher spontaneous excretion in urine and the mobilizing effect after calcium versenate (CaEDTA) administration and an increased blood lead level pointed to an increased lead flow in the organism for a comparatively long period.

About 15 years ago Schmid and Shemin (1955) separated from duck erythrocytes a very clear protein fraction which caused a change of delta-aminolevulinic acid (ALA) to porphobilinogen. In the same year this discovery was made by Gibson, Neuberger, and Scott (1955), who separated this enzyme from bull liver and called it ALA-dehydrase (ALA-D). They found this enzyme to be widely spread in nature and probably present in all cells with aerobic metabolism. In mammals, most of it is found in liver, kidney and bone-marrow. They also pointed to the favourable effect which cysteine and glutathion have upon an increase of enzyme activity and they concluded that activity is bound up with the presence of $-\mathrm{SH}$ groups. They also found that EDTA strongly inhibits this enzyme. It was soon determined that sodium malonate and lead inhibit this enzyme (Goldberg, Ashenbrucker, Cartwright, and Wintrobe, 1956), and this finding has subsequently been confirmed. According to Rubino (1962), lead in a concentration $10^{-5} \mathrm{M}$ almost completely inhibits ALA-D and, according to Lichtman and Feldman (1963), it inactivates the -SH groups of the enzyme. Heilmeyer (1963) states that the inhibition of this dehydrase is entirely reversible.

The above-mentioned authors investigated the activity of the enzyme mainly in erythrocytes by comparatively complicated methods. Recently, Bon- 
signore and his colleagues (Bonsignore, Calissano, and Cartasegna, 1965) described a simple method and confirmed considerable inhibition of ALA-D in lead poisoning; De Bruin (1968) repeated this in experimental poisoning in man and concluded that ALA-D is a test which is exceedingly sensitive to lead. For this reason we decided to apply it in persons who had been poisoned by lead in the past but had not been working with lead for a long time. We had already shown that these persons continue to excrete lead in excess for many years, despite mobilizing CaEDTA injections.

\section{Methods}

Twenty-seven former patients at the clinic, who had been treated several years previously for chronic lead poisoning, were examined. None of them had worked with lead since treatment. The time since the last exposure to lead was between 3 and 5 years in 13 workers, between 8 and 11 years in 2, 13 years in 11 , and 17 years in one worker. Besides a normal clinical examination, the following tests were carried out: blood lead, urinary lead, haemoglobin, stippled red cell count, coproporphyrin in urine, and ALA in urine (Grabecki, Haduch, and Urbanowicz, 1967). Finally, ALA-dehydrase was determined by the method of Bonsignore and his colleagues (1965). Then lead mobilization was carried out in all by an intravenous injection of $2 \mathrm{~g} \mathrm{CaNa}_{2}$ EDTA by the method which we described for out-patient practice (Teisinger and Srbová, 1959) and according to which the mean value in unexposed persons amounts to $0.145 \mathrm{mg} \mathrm{Pb} / 24$ hours $(0.058$ to 0.352). For comparison, the activity of ALA-D was also determined in a control group of 25 persons in whom there had been no contact with lead.

\section{Results}

The values of ALA-D for the control group are shown in Table 1 and the findings in the 27 workers previously exposed to lead are given in Table 2 .

In all persons examined the values of haemoglobin, stippled red cell count, and coproporphyrin in urine were normal. ALA values in urine were normal with a mean of $6.5 \mathrm{mg} / \mathrm{l}$, and did not differ from our control group. Increased values were found in only two persons (cases 7 and 9) who had comparatively high values of blood lead and who had ended their exposure to lead only three or four years previously.

The blood lead and urinary lead levels before CaEDTA injection are worthy of note. The mean blood lead level was $0.046 \mathrm{mg} \%$ (range 0.023 to $0.078 \mathrm{mg} \%$ ); in two cases it was higher than $0.070 \mathrm{mg} \%$. The mean urinary lead value was $0.056 \mathrm{mg} / \mathrm{l}$. Both these values exceed the means given for a normal unexposed population $(0.017 \mathrm{mg} \%$, $\mathrm{SD}=0.011$, or $0.035 \mathrm{mg} / \mathrm{l}, \mathrm{SD}=\mathbf{0 . 0 1 4}$, according to Goldwater and Hoover (1967); according to our research $0.037 \mathrm{mg} / \mathrm{l}$ for urine).

In 22 cases the mobilization test was positive (more
TABLE 1

Control Group

\begin{tabular}{|c|c|c|c|}
\hline Case & Year of birth & Sex & $\begin{array}{c}\text { ALA- } \\
\text { dehydrase } \\
\text { (units } / \mathrm{ml} \text { ) }\end{array}$ \\
\hline $\begin{array}{r}1 \\
2 \\
3 \\
4 \\
5 \\
6 \\
7 \\
8 \\
9 \\
10 \\
11 \\
12 \\
13 \\
14 \\
15 \\
16 \\
17 \\
18 \\
19 \\
20 \\
21 \\
22 \\
23 \\
24\end{array}$ & $\begin{array}{l}1902 \\
1950 \\
1932 \\
1923 \\
1915 \\
1923 \\
1908 \\
1919 \\
1926 \\
1916 \\
1935 \\
1922 \\
1911 \\
1930 \\
1933 \\
1939 \\
1897 \\
1935 \\
1923 \\
1914 \\
1927 \\
1912 \\
1938 \\
1911\end{array}$ & $\begin{array}{l}\text { M } \\
\text { M } \\
\text { F } \\
\text { F } \\
\text { F } \\
\text { M } \\
\text { M } \\
\text { M } \\
\text { F } \\
\text { M } \\
\text { M } \\
\text { M } \\
\text { F } \\
\text { F } \\
\text { F } \\
\text { F } \\
\text { M } \\
\text { F } \\
\text { F } \\
\text { F } \\
\text { F } \\
\text { F } \\
\text { F } \\
\text { F }\end{array}$ & $\begin{array}{r}123 \\
125 \\
142 \\
143 \\
136 \\
111 \\
95 \\
141 \\
116 \\
109 \\
97 \\
114 \\
104 \\
134 \\
125 \\
141 \\
96 \\
101 \\
98 \\
102 \\
90 \\
114 \\
132 \\
108\end{array}$ \\
\hline \multicolumn{4}{|c|}{$\begin{aligned} \text { Mean } & =116.54 \\
\text { SD } & =17.13\end{aligned}$} \\
\hline
\end{tabular}

than $0.350 \mathrm{~Pb} \mathrm{mg} / 24$ hours) and the ALA-D activity was considerably reduced. (In only one case with slightly increased mobilization was the ALA-D normal.) In three cases with a normal lead mobilization the ALA-D was decreased. Finally, in a further two cases, a normal mobilization result was associated with normal ALA-D. It may be concluded that in practically all cases showing increased mobilization (the maximum values of which amounted to approximately $2 \mathrm{mg} / 24$ hours) the ALA-D activity was decreased.

In the control group the mean activity of ALA-D was 116.5 units (range 90 to 143).

On clinical examination of the exposed group, six were found to have hypertension, others had suffered from cardiac infarction, carcinoma of the prostate or lung, or chronic bronchitis.

\section{Discussion}

All patients whom we studied had suffered from chronic lead poisoning at some time and had not worked with lead since their attack for several years, many of them for 13 years, and one for 17 years. Despite these long intervals since their last exposure, they continue to excrete, on average, considerably more lead in the urine than the unexposed population, also the mean blood lead level is higher. The 
TABLE 2

Findings in 27 Workers Previously Exposed to LeAd

\begin{tabular}{|c|c|c|c|c|c|c|c|c|}
\hline \multirow{2}{*}{ Case } & \multirow{2}{*}{$\begin{array}{c}\text { Year } \\
\text { of } \\
\text { birth }\end{array}$} & \multirow{2}{*}{$\begin{array}{c}\text { Exposure } \\
\text { (years) }\end{array}$} & \multirow{2}{*}{$\begin{array}{c}\text { Years after } \\
\text { exposure }\end{array}$} & \multirow[b]{2}{*}{$\begin{array}{c}\text { Blood lead } \\
\text { level before } \\
\text { CaEDTA } \\
(m g \%)\end{array}$} & \multicolumn{2}{|c|}{ Urinary lead } & \multirow{2}{*}{$\begin{array}{l}\text { ALA-D } \\
\text { before } \\
\text { CaEDTA } \\
\text { (units } / \mathrm{ml})\end{array}$} & \multirow{2}{*}{$\begin{array}{c}\text { ALA in } \\
\text { urine } \\
(m g / l)\end{array}$} \\
\hline & & & & & $\begin{array}{l}\text { Before } \\
\text { EDTA } \\
(m g / l)\end{array}$ & $\begin{array}{c}\text { After } \\
\text { EDTA } \\
(m g / 24 h r)\end{array}$ & & \\
\hline $\begin{array}{r}1 \\
2 \\
3 \\
4 \\
5 \\
6 \\
7 \\
8 \\
9 \\
10 \\
11 \\
12 \\
13 \\
14 \\
15 \\
16 \\
17 \\
18 \\
19 \\
20 \\
21 \\
22 \\
23 \\
24 \\
25 \\
26 \\
27\end{array}$ & $\begin{array}{l}1905 \\
1904 \\
1924 \\
1917 \\
1907 \\
1906 \\
1906 \\
1904 \\
1910 \\
1905 \\
1907 \\
1903 \\
1924 \\
1899 \\
1901 \\
1939 \\
1920 \\
1897 \\
1931 \\
1905 \\
1911 \\
1923 \\
1898 \\
1902 \\
1902 \\
1912 \\
1926\end{array}$ & $\begin{array}{c}15 \\
40 \\
11 \\
6 \mathrm{mth} \\
29 \\
30 \\
35 \\
29 \\
20 \\
36 \\
20 \\
5 \\
3 \\
26 \\
36 \\
3 \\
5 \mathrm{mth} \\
9 \mathrm{mth} \\
2 \frac{1}{2} \\
2 \\
7 \\
5 \\
2 \\
8 \\
3 \\
4 \\
3\end{array}$ & $\begin{array}{r}5 \\
5 \\
4 \\
5 \\
3 \\
4 \\
3 \\
5 \\
4 \\
4 \\
3 \\
4 \\
4 \\
17 \\
8 \\
11 \\
13 \\
13 \\
13 \\
12 \\
13 \\
13 \\
13 \\
13 \\
13 \\
13 \\
13\end{array}$ & $\begin{array}{l}0.062 \\
0.049 \\
0.068 \\
0.043 \\
0.049 \\
0.055 \\
0.078 \\
0.048 \\
0.071 \\
0.044 \\
0.030 \\
0.023 \\
0.031 \\
0.049 \\
0.043 \\
0.062 \\
0.037 \\
0.041 \\
0.043 \\
0.037 \\
0.031 \\
0.062 \\
0.037 \\
0.043 \\
0.037 \\
0.037 \\
0.043\end{array}$ & $\begin{array}{l}0.070 \\
0.060 \\
0.054 \\
0.077 \\
0.044 \\
0.060 \\
- \\
0.040 \\
0.050 \\
0.050 \\
0.040 \\
0.030 \\
-\overline{0} \\
0.022 \\
0.051 \\
0.068 \\
0.031 \\
0.058 \\
0.064 \\
0.062 \\
0.034 \\
0.103 \\
0.063 \\
0.069 \\
0.096 \\
0.085 \\
0.038\end{array}$ & $\begin{array}{l}1.921 \\
1.605 \\
1.966 \\
0 \cdot 310 \\
1.992 \\
0.985 \\
2 \cdot 178 \\
0 \cdot 864 \\
2 \cdot 357 \\
1 \cdot 137 \\
0 \cdot 721 \\
0 \cdot 425 \\
0 \cdot 337 \\
0 \cdot 647 \\
0 \cdot 877 \\
0 \cdot 930 \\
0 \cdot 298 \\
0 \cdot 406 \\
1 \cdot 234 \\
0 \cdot 398 \\
0 \cdot 290 \\
0 \cdot 554 \\
0 \cdot 328 \\
0 \cdot 719 \\
0 \cdot 423 \\
1 \cdot 216 \\
1 \cdot 106\end{array}$ & $\begin{array}{r}19 \\
36 \\
12 \\
98 \\
38 \\
17 \\
6 \\
23 \\
28 \\
53 \\
49 \\
61 \\
73 \\
35 \\
28 \\
56 \\
96 \\
96 \\
32 \\
42 \\
51 \\
56 \\
46 \\
48 \\
72 \\
57 \\
53\end{array}$ & $\begin{array}{c}7 \cdot 9 \\
7 \cdot 6 \\
4 \cdot 3 \\
4 \cdot 3 \\
7 \cdot 6 \\
6 \cdot 9 \\
15 \cdot 8 \\
5 \cdot 6 \\
13 \cdot 85 \\
7 \cdot 6 \\
5 \cdot 6 \\
6 \cdot 6 \\
2 \cdot 9 \\
7 \cdot 2 \\
5 \cdot 2 \\
4 \cdot 6 \\
5 \cdot 6 \\
3 \cdot 9 \\
8 \cdot 9 \\
5 \cdot 3 \\
4 \cdot 7 \\
7 \cdot 6 \\
2.9 \\
8 \cdot 3 \\
7 \cdot 6 \\
5 \cdot 2 \\
3 \cdot 3\end{array}$ \\
\hline & & $95 \%$ confid & $\begin{array}{r}\mathrm{n} \\
\text { Mean } \\
\text { SEM } \pm \\
\text { ce limits } \pm\end{array}$ & $\begin{array}{l}27 \\
0.0464 \\
0.00259 \\
0.0053\end{array}$ & $\begin{array}{l}25 \\
0.0568 \\
0.00404 \\
0.0083\end{array}$ & $\begin{array}{r}27 \\
0.971 \\
0.124 \\
0.255\end{array}$ & $\begin{array}{r}27 \\
47 \cdot 44 \\
4 \cdot 73 \\
9 \cdot 75\end{array}$ & $\begin{array}{l}27 \\
6 \cdot 55 \\
0 \cdot 566 \\
1 \cdot 17\end{array}$ \\
\hline
\end{tabular}

The workmen were employed in the accumulator plant, lead smelting plant, lead ore mine, minium production, enamel spraying and lead paint removing.

results of the mobilization test suggest an increased lead deposit in the body.

All persons studied had had considerable exposure to lead, but the length of exposure differed. In cases 4,17 , and 18 the exposure had only lasted for several months, and this is manifested in the mobilization test and by the fact that the ALA-dehydratase activity is practically normal at the present time. Obviously lead excretion from deposited lead continues for a much shorter time in these cases than in subjects in whom the lead deposit was accumulated over years of exposure.

It is evident from our previous reports (Teisinger and Srbová, 1959; Teisinger et al., 1969) that after the termination of exposure lead is excreted for a considerable period from the mineral part of bones. It may be assumed that it is firmly bound in bone and is probably built into the crystallic lattice of hydroxyapatite. It is probably released only slowly from these bonds as part of the normal bone metab- olism. Thus there is a slight, permanent rèlease of lead which is partly, and for a temporary period, deposited in soft tissues before excretion.

Hitherto, it has not been possible to demonstrate any biological activity of this 'bone' lead, because the tests available have not been sufficiently sensitive. The discovery of a new, highly sensitive test with ALA-D has afforded evidence that this stored lead is biologically active. This is evident from Table 2, which shows that the activity of ALA-D is decreased in practically all the cases of past lead poisoning, which now show an increased mobilization test, and in several cases in which this test was negative.

A very small lead concentration in blood is sufficient to cause a reduction of ALA-D activity in erythrocytes. De Bruin (1968) found a slight inhibition after intravenous injection in rabbits even with a concentration of lead in blood of $2 \times 10^{-7}$ molar, this corresponding in his opinion to a blood lead level of 10 to $15 \mu \mathrm{g} \%$. In our group, the lead con- 
centration in blood was approximately $2.5 \times 10^{-6}$ molar.

If persons in the group studied by us have a decreased activity of this enzyme such a long time after exposure, it may be assumed that this condition had also prevailed during exposure. It seems obvious that in these persons activity of this enzyme had been reduced for many years, even for as long as 45 years! This means that some members of our group had been deficient in ALA-D for more than half their life. Yet it is not possible to determine either from their history or from clinical examination any relevant disturbance of health. Obviously the human organism is capable of compensating these small damages in some other manner.

From our observations we may conclude that the determination of ALA-D activity is such a sensitive test and capable of demonstrating the presence of such negligible lead concentrations that it will be unsuitable for hygiene practice.

On the other hand, the finding that lead is biologically active in very low concentrations raises a host of questions. What other enzymes or biological systems are affected by lead and perhaps by other metals? And do these effects have any practical or even detectable results on the health of the people exposed?

\section{References}

Bonsignore, D., Calissano, P., and Cartasegna, C. (1965). Un semplice metodo per la determinazione della delta-amino-levulinicodeidratasi nel sangue. Med. $d$. Lavoro, 56, 199-205.

De Bruin, A. (1968). Effect of lead exposure on the level of deltaamino-levulinic-dehydratase-activity. Med. $d$. Lavoro, 59, 411-418.

Gibson, K. D., Neuberger, A., and Scott, J. J. (1955). The purification and properties of delta-aminolaevulic acid dehydrase. Biochem.J., 61, 618-629.

Goldberg, A., Ashenbrucker, H., Cartwright, G. E., and Wintrobe, M. M. (1956). Studies on the biosynthesis of heme in vitro by avian erythrocytes. Blood, 11, 821-833.

Goldwater, L. J., and Hoover, A. W. (1967). An international study of 'normal' levels of lead in blood and urine. Arch. environm. Hlth, 15,60 .

Grabecki, J., Haduch, T., and Urbanowicz, H. (1967). Die einfachen Bestimmungsmethoden der delta-Aminolävulinsäure im Harn Int. Arch. Gewerbepath. Gewerbehyg., 23, 226-240.

Heilmeyer, L. (1963). Neue Ergebnisse der PorphyrinstoffwechselForschung. Münch. med. Wschr., 105, 277-286.

Lichtman, H. C., and Feldman, F. (1963). In vitro pyrrole and porphyrin synthesis in lead poisoning and iron deficiency. J. clin. Invest., 42, 830-839.

Rubino, G. F. (1962). The role of lead in porphyrin metabolism. Panminerva med., 4, 340-344.

Schmid, R., and Shemin, D. (1955). The enzymatic formation of porphobilinogen from delta-aminolevulinic acid and its conversion to protoporphyrin. J. Amer. chem. Soc., 77, 506-507.

Teisinger, J., Přerovská, I., Šedivec, V., Flek, J., and Roth, Z. (1969). Attempt on determination of biologically active lead in organism in experimental poisoning. Int. Arch. Gewerbepath. Gewerbehyg., 25, 240-255.

, and Srbová, J. (1959). The value of mobilization of lead by calcium ethylene-diamine-tetra-acetate in the diagnosis of lead poisoning. Brit. J. industr. Med., 16, 148-152.

Received for publication February 2, 1970 